Wiktor Figiel

V Liceum Ogólnokształcące

im. gen. Jakuba Jasińskiego we Wrocławiu

\section{Katarzyna Kuczyńska}

Wrocławskie Centrum Doskonalenia Nauczycieli

Wojciech Ostrowski

Instytut Filozofii, Uniwersytet Wrocławski

\section{Aldona Pobojewska}

Instytut Filozofii, Uniwersytet Łódzki

\section{Sebastian Wachowiak}

Szkoła Podstawowa nr $3 \mathrm{im}$. Mariusza Zaruskiego we Wrocławiu, Mała Uczelnia we Wrocławiu

\section{Jolanta Zwiernik}

Wydział Nauk Pedagogicznych

Dolnośląska Szkoła Wyższa we Wrocławiu

\section{Andrzej Krajna}

Centrum Edukacji Nauczycielskiej

Uniwersytet Wrocławski

\section{Elżbieta Małkiewicz}

Centrum Edukacji Nauczycielskiej

Uniwersytet Wrocławski

\section{Krystian Piątek}

Fundacja Uniwersytet Dzieci

\section{Maria Reut}

Wydział Nauk Pedagogicznych

Dolnośląska Szkoła Wyższa we Wrocławiu

\section{Pawel Wróblewski}

Instytut Filozofii, Uniwersytet Wrocławski

\title{
KOMENTARZ DO OPUBLIKOWANEGO PROJEKTU PODSTAW PROGRAMOWYCH NAUCZANIA ETYKI W SZKOLE PODSTAWOWEJ
}

\begin{abstract}
Abstrakt
Tekst jest komentarzem do projektu podstaw programowych nauczania etyki, opublikowanego przez MEN w 2016 roku w związku z reformą szkolnictwa. Autorzy zwracają uwagę na mankamenty projektu: zawężanie przedmiotu etyki do wyuczonych norm zachowania, nadmierny nacisk położony na przyswajanie wiedzy pojęciowej, brak miejsca na praktyczne rozwijanie zdolności refleksji poprzez dyskusje i sytuacje problemowe. Wskazują na niedostosowanie programu do psychoemocjonalnego poziomu rozwoju uczniów na tym etapie kształcenia, a także brak spójności między poszczególnymi punktami projektu.
\end{abstract}

\section{Slowa kluczowe:}

nauczanie etyki, podstawa programowa, polska szkoła podstawowa 


\section{WPROWADZENIE*}

Przedstawione na stronie internetowej Ministerstwa Edukacji Narodowej projekty podstaw programowych do etyki budzą, w naszej ocenie, liczne wątpliwości. Pierwsza z nich dotyczy faktu, że w odniesieniu do edukacji wczesnoszkolnej zaprezentowano dwa projekty, nie wyjaśniając ich wzajemnej relacji. W wyniku dokonanych $\mathrm{w}$ interdyscyplinarnym zespole analiz formułujemy ocenę, że projekt podstawy programowej do etyki ujęty w pliku Edukacja wczesnoszkolna wymaga pewnych korekt, ale stanowi obiecujący materiał, także w odniesieniu do dotychczas obowiązujących podstaw programowych etyki w edukacji wczesnoszkolnej. Natomiast projekt zaprezentowany w pliku Etyka (podzielony na wymagania wobec I i II poziomu) zawiera istotne błędy tak pedagogiczne, jak i merytoryczne. Ponieważ czas prekonsultacji jest bardzo krótki, nie udało nam się sformułować konstruktywnych uwag do materiału opracowanego w ramach kompleksowej podstawy programowej edukacji wczesnoszkolnej. Jesteśmy gotowi zaangażować się w prace nad takim komentarzem, jeśli Autorzy będą na współpracę otwarci. W prezentowanej analizie skupiliśmy się na materiale zawartym w pliku Etyka, odnośnie do którego uważamy, że w aktualnej postaci nie powinien zostać prawnie zatwierdzony. Wprawdzie dotychczasowe podstawy programowe do etyki na pewno nie są satysfakcjonujące - pochodzą z czasów, kiedy kultura nauczania etyki dopiero się rodziła, i ową niedojrzałość wyraźnie sobą reprezentują, jednak nie zyskuje naszej aprobaty sytuacja, w której reforma oświaty oznacza regres edukacji etycznej.

\footnotetext{
* Uwagi Katarzyny Kuczyńskiej z dnia 6 XI 2018 roku: Tekst został opracowany przez interdyscyplinarny zespół nauczycieli szkolnych i akademickich. Komentarz powstał w grudniu 2016 roku - gdy ukazały się projekty podstaw programowych do nauczania poszczególnych przedmiotów w zreformowanej szkole podstawowej a następnie średniej. Reforma została przeprowadzona. Komentowany przez nas projekt edukacji etycznej na poziomie wczesnoszkolnym (Projekt pod nazwą Podstawa programowa kształcenia ogólnego z komentarzem. Szkoła Podstawowa. Etyka dostępny jest pod adresem: https://www.ore.edu.pl/wp-content/uploads/2017/ 05/etyka.-pp-z-komentarzem.-szkola-podstawowa-1.pdf.) został zastąpiony innym dokumentem, będącym redakcją (z niewielką ilością zmian przede wszystkim stylistycznych) projektu stanowiącego integralną część Edukacji wczesnoszkolnej. O zdublowaniu się obu projektów wspomnieliśmy w Komentarzu. Drugi dokument nie był przedmiotem naszych szczegółowych analiz, wszelako dokonaną zamianę należy uznać za fortunną. Projekt podstawy programowej nauczania etyki w klasach IV-VIII szkoły podstawowej został z kolei wyraźnie rozbudowany w stosunku do materiału wstępnego (Projekt pod nazwą Podstawa programowa - etyka dostępny jest pod adresem: https://men.gov.pl/wp-content/uploads/2016/11/podstawa-programowa-\%E2\%80\%93-etyka-.pdf).
} 
ANALIZA PROJEKTU PODSTAW PROGRAMOWYCH Z ETYKI

I etap edukacyjny, edukacja wczesnoszkolna: klasy I-III

Zaprezentowane cele ksztalcenia nie zawierają spójnego obrazu horyzontu aksjologicznego, do którego odwoływać miałyby się zajęcia z etyki - nie opierają się na żadnej wizji świata czy chociażby porządku kulturowego, w ramach którego budowane są specyficzne dla współczesnych ludzi doświadczenia moralne. Tym samym nie wskazują podstawowych dla tych doświadczeń wartości, hierarchii ich ważności i wzajemnych zależności między nimi. Spośród wartości wymieniony zostaje tylko szacunek, punkty od 2 do 5 są sformułowane ogólnikowo. Nie dostrzegamy tu kompatybilności celów kształcenia z treściami nauczania. Wyrażenia czasownikowe, w których sformułowane są wymagania ogólne, sugerują, że moralność i etyka to jednoznacznie zdefiniowany obszar ludzkiej aktywności, a zadaniem edukacji etycznej jest przede wszystkim wyposażenie ucznia w jednoznaczną, „twardą” wiedzę o zjawiskach moralnych, pozytywnych i negatywnych. Żaden $\mathrm{z}$ wymienionych celów kształcenia nie wskazuje na budzenie czy rozwijanie u uczniów umiejętności namysłu nad zjawiskami moralnymi. W każdym punkcie wymagań ogólnych położony został akcent na zdobycie określonej wiedzy, punkty 1 i 5 wzbogacono o umiejętność ,wyrażania” wiedzy oraz „przestrzegania" dyspozycji zawartych w wyuczonych zasadach zachowania.

O tym, że opracowane cele dają świadectwo dość ograniczonego rozumienia, czym jest doświadczenie moralne człowieka, w tym także dziecka, świadczy sformułowanie ,zna i aprobuje dobre zachowania, dostrzega i nie aprobuje (nie wyraża pozytywnych emocji) zachowań złych", sprowadzające akty moralne do emocjonalnej reakcji. Redukcjonistyczne pojmowanie doświadczenia moralnego, jakie zostało przedstawione w kontekście sformułowanych celów kształcenia, grozi zawłaszczeniem edukacji etycznej przez standardy i metody pedagogiki behawioralnej. Od początku swojej edukacyjnej drogi młody człowiek traktowany jest jak przedmiot oddziaływań, a nie jak podmiot działań moralnych. Czy ma to w jego dalszym życiu owocować - co dokładnie zaprojektowali Autorzy - sprowadzeniem aktywności moralnej do wyrażanej emocjonalnie aprobaty lub dezaprobaty? Uważamy, że nie taki powinien być cel edukacji etycznej, tym bardziej nie znajdujemy uzasadnienia dla tego, że to, co uważamy za najistotniejsze $\mathrm{w}$ procesie kształcenia $\mathrm{w}$ ramach zajęć $\mathrm{z}$ etyki - budzenie i rozwijanie refleksyjności i wrażliwości aksjologicznej ucznia - pojawia się jako postulat we fragmencie Warunki realizacji. W warstwie semantycznej tekstu jest to pustosłowie, ale jako fragment dokumentu normatywnego lokuje nauczyciela etyki w sytuacji sprzeczności performatywnej. 
Opracowane Treści nauczania - wymagania szczegółowe odsłaniają kolejne słabości przedstawionego projektu podstawy programowej:

a) Wymagania szczegółowe dotyczą przede wszystkim czynności intelektualnych (dostrzega, podaje przyktady, wie, wymienia, zna i objaśnia, wykorzystuje podstawowe pojęcia moralne do charakteryzowania bohaterów, rozumie, dostrzega wartość). Rzadko obecne są czasowniki wyrażające kompleksowo postawy, umiejętności - wyjątkowo pod tym względem potraktowano ponownie szacunek, któremu poświęcono 3 z 4 punktów Postępowania wobec innych ludzi, jakkolwiek we wszystkich tych rozwinięciach uczeń „stara się okazywać szacunek" (rozwinięcia dotyczą kolejnych kategorii osób, nie zaś samego procesu okazywania lub doświadczania szacunku). Z treści nauczania jest całkowicie wyrugowana sfera rozwoju emocjonalnego - nie mówi się o różnorodnych emocjach dziecka i konieczności rozwijania tej sfery, nie ma nic o jego wrażliwości, wstydzie, pragnieniach, radości itp. (raz jeden Autorzy postulują zakazywanie uczniom wyrażania pozytywnych emocji w stosunku do złych zachowań, wszelako trudno to uznać za postulat rozwijania inteligencji emocjonalnej uczniów). Ta integralna część człowieczeństwa, i tym samym moralności, nie została przez Autorów uznana za istotny element edukacji etycznej. Przy czym postulat, by na lekcjach etyki wspierać rozwój emocjonalny dziecka, nie dotyczy tylko zawarcia określonych treści w wymaganiach szczegółowych. Wyraża on także oczekiwanie, że w części podstawy programowej omawiającej warunki realizacji zajęć będą wyraźne dyspozycje metodyczne, jak tę sferę emocjonalną rozwijać poprzez stosowanie określonych form i sposobów pracy z dziećmi na różnych zajęciach.

Ubóstwem cechuje się również przestrzeń wartości i postaw zaprojektowana przez Autorów. Przede wszystkim rzuca się w oczy potraktowanie złożonych zjawisk moralnych i społecznych jako oczywistych desygnatów jednoznacznych pojęć - uczeń zna i objaśnia wybrane podstawowe pojęcia zwiazane z ocena moralna: dobro, zło, odpowiedzialność; rozumie, czym jest sprawiedliwość, patriotyzm; uczeń potrafi wymienić różne zalety $i$ wady człowieka. Z niepokojem przyjmujemy również zawartą $\mathrm{w}$ podstawie programowej in extenso silnie wyeksponowaną tezę o obowiązywalności uniwersalnych zasad $i$ wartości, opartą na pozornej oczywistości i wykluczającą odmienne doświadczenia epistemiczne i aksjotyczne. Dominantą w aksjologicznym pejzażu projektu jest szacunek - poświęcono mu trzy z czterech punktów w części II, ale w żadnych z nich nie zaproponowano refleksji nad pojęciem szacunku, wręcz przeciwnie - podane przykłady (uczeń stara się okazywać szacunek) wskazują na instrumentalne rozumienie okazywania szacunku przez ucznia jako formy kontroli nad jego zachowaniem. Z kolei jako „pakiet” postaw i relacji w Postepowaniu wobec innych ludzi wystarczył Autorom 1 punkt. Być może dzięki temu redukcjonizmowi nie trzeba się nam teraz, w trakcie analizy, mierzyć z trywializacją miło- 
ści, życzliwości, koleżeństwa, wdzięczności i tolerancji. Niemniej, dokonana strukturalizacja treści jawi się jako nieprzemyślana i przypadkowa. Podobnie nieuzasadnione jest przyporządkowanie, również $\mathrm{W}$ postaci wyliczanki, uczciwości, odwagi, sumienności, pracy i honoru do obszaru Postepowanie wobec siebie. Sprzeciw budzi instrumentalizacja kategorii godności ludzkiej, która w projekcie pojawia się w 2 punkcie Elementów propedeutyki myślenia moralnego wprost $\mathrm{i}$ - jak mniemamy - opisowo w Postępowaniu wobec siebie w punkcie 1 (ponadto jeszcze we fragmencie ostatnim). W drugim przypadku znaczenie godności okazuje się sprowadzone do bilansu zalet i wad. Pytania budzi fragment V: Skoro uczeń wie, dlaczego nie powinno się krzywdzić zwierzat, a zarazem podaje przykłady madrego korzystania z dobrodziejstw przyrody, to czy Autorzy rozpoznają konsekwencje takiego ujęcia sprawy? Czy przewidują, że wymaga to zakwestionowania dominujących w przemyśle spożywczym praktyk (co może się okazać problematyczne w związku z wrażliwością dzieci w tym wieku) oraz uznania wartości życia każdego zwierzęcia? Jak bowiem można zabić zwierzę, nie wyrządzając mu krzywdy? Fragment ten wygląda na kolejny przykład nierefleksyjnego określenia treści nauczania przez Autorów.

b) Zdumiewa nas obraz możliwości werbalnych i analitycznych dziecka, jaki towarzyszył twórcom projektu. Zaproponowana struktura problemowa przypomina strukturę podręcznika akademickiego - z dydaktyki akademickiej najwyraźniej pochodzi zwyczaj rozpoczynania zajęć od propedeutyki (czyli teoretycznego wstępu do jakiejś dziedziny wiedzy). Wyróżniona kategoria postępowanie (organizująca cztery $\mathrm{z}$ pięciu działów treści nauczania) jest odległa od doświadczenia dziecka, które na tym etapie rozwojowym dokonuje rozróżnień na siebie, inne konkretne osoby, konkretne elementy rzeczywistości, np. ubranie, piórnik, przedszkole, dom itd., i (zazwyczaj przy pomocy nauczyciela) potrafi to $\mathrm{w}$ miarę precyzyjnie opisać. Jednak nie abstrahuje swoich działań - postępowania - i nie kategoryzuje ich ze względu na arbitralnie przyjęte kategorie, które w wyborze Autorów to: inni ludzie, ja, dobro wspólne, przyroda. Tym bardziej kuriozalny jest wymóg, aby uczeń edukacji wczesnoszkolnej wymieniat elementy niezbędne do charakterystyki działania $w$ aspekcie jego moralnej oceny oraz znat $i$ objaśniat podstawowe pojęcia zwiąane z ocena moralna (zob. Treści nauczania, I.3).

Oddziaływania edukacyjne są możliwe, gdy nauczyciel porusza się w strefie najbliższego rozwoju swoich uczniów (zob. koncepcja Lwa S. Wygotskiego oraz założenia konstruktywizmu). Rozwój intelektualny dziecka w wieku wczesnoszkolnym dokonuje się głównie poprzez obrazy i działania (zob. wyobrażenia przedoperacyjne i początek operacji konkretnych według ciągle aktualnej koncepcji rozwoju intelektualnego Jeana Piageta). Trudno nam zlokalizować pedagogiczne koncepcje czy epistemologiczne autorytety, z których Autorzy wywodzą postulat, że ważnym - i szczególnie trudnym - zadaniem 
nauczyciela, jest stopniowe wprowadzanie i objaśnianie podstawowych pojęć etycznych, za pomoca których będzie możliwe efektywniejsze realizowanie konkretnych zadań z zakresu edukacji etycznej. Intryguje nas także, kto będzie mógł efektywniej realizować konkretne zadania z zakresu edukacji etycznej: uczeń czy nauczyciel? I jakie to zadania? Znalezienia odpowiedzi nie ułatwia fakt, że fragment niejasnego zdania (będzie możliwe efektywniejsze realizowanie konkretnych zadań z zakresu) jest kalką z języka zarządzania.

c) Zostawiając na chwilę kwestię nieadekwatności zaproponowanych treści nauczania do możliwości psychorozwojowych uczniów, zajmiemy się teraz filozoficznym pytaniem: jaka teleologia inspirowała Autorów przy konstruowaniu omawianej struktury wiedzy do nauczenia? W jaki sposób rozumieją oni proces wychowawczy, proces wspierania dzieci w budowaniu etycznej podmiotowości, skoro za najlepszy środek do tego uznali intelektualne ćwiczenie uczniów w taksonomii zjawisk moralnych? Mamy poważne obawy, że za pomocą zaprezentowanego projektu podstawy programowej dokonuje się przeniesienie na grunt edukacji najmłodszych najpoważniejszej wady etyki jako dyscypliny akademickiej - Etyka skupia dziś uwagę głównie na kwestiach drugorzędnych albo incydentalnych $w$ obszarze całości życia człowieka, chętnie milczac o pierwszorzędnych $i$ tyczacych człowieka nie okazjonalnie, lecz permanentnie, i to każdego, a nie nielicznych. Wymyślamy problemy, które nas bezpośrednio nie dotycza, by nie myśleć o tych, które dotycza nas bezpośrednio. Tematyzujemy to, co stematyzować tatwiej i co bardziej spektakularne, a mniej ryzykowne. Wyglada to tak, jakby etyczność była $w$ życiu czlowieka charakterystyka jakiegoś incydentu, a nie dotyczyła catości jego życia, jego catościowego zorientowania ${ }^{1}$.

Jako grono osób prowadzących zajęcia z etyki na wszystkich poziomach edukacyjnych oraz przygotowujących tych, którzy będą je prowadzić, uważamy, że naszym głównym zadaniem jest pobudzanie, podtrzymywanie, rozwijanie wrażliwości u naszych uczniów na to, co czynią. Najważniejsze są własne doświadczenia etyczne ucznia $\mathrm{i}$ ich analiza $\mathrm{z}$ uwzględnieniem także sfery uczuciowej (wrażliwości, altruizmu) i odpowiedzialności za własne działania oraz możliwości naprawienia własnych niewłaściwych zachowań. Dlatego staramy się wspierać uczniów w refleksyjnym przeżywaniu świata, w tym, co tutaj $i$ teraz czują, myślą, wyrażają swoim zachowaniem, a zatem - naszym zdaniem - programy nauczania i fundujące je podstawy programowe powinny czynić punktem wyjścia doświadczenie współczesnych dzieci, a komponenty edukacyjne (wiedza, umiejętności, kompetencje, postawy) powinny być kształtowane w ramach tego doświadczenia. Nie rozumiemy intencji ani sensu narzucania uczniom abstrakcyjnych konstruktów do nazywania (bo przecież nie

\footnotetext{
${ }^{1}$ Jacek Filek, Filozofia jako etyka, http://portal.tezeusz.pl/cms/tz/index.php?id=420 [dostęp: 2.12.2016].
} 
rozumienia) tego, w czym uczestniczą i co współtworzą. Werbalizm jest doskonałym narzędziem biurokracji edukacyjnej, ale duchowo, nawet gdy intelektualnie jest wyrafinowany, wyjaławia.

Zwracamy także uwagę na logiczno-językowe braki opublikowanego projektu podstawy programowej. Poza licznymi błędami interpunkcyjnymi, obecne są błędy składniowe (np. punkt 3 części I; punkty 1-3 IV; punkt 1 V), stylistyczne (redakcja fragmentu II oraz V). Wyjątkowe wyzwania przed czytelnikiem stawia fragment $\mathrm{z}$ antycypującym je tytułem Zalecane realizacje, $w$ tym zadania nauczyciela. Przykładem szczodrej redundancji jest zdanie trzecie, podobnie zdania piąte i dwunaste. W stosunku do wymagań ogólnych i szczegółowych zdania dziewiąte oraz trzynaste, czternaste i piętnaste niniejszego fragmentu pozostają $\mathrm{w}$ sprzeczności.

Przeprowadzona przez nas analiza nie jest wyczerpująca, z powodu krótkiego terminu prekonsultacji ograniczyliśmy się do omówienia najważniejszych dla nas kwestii.

\section{II etap edukacyjny, szkoła podstawowa: klasy IV-VIII}

Analiza materiału dotyczącego II poziomu edukacyjnego doprowadziła nas do powtórzenia części konkluzji z analizy podstawy programowej do etyki na poziomie I, tym bardziej że w sporych fragmentach materiały są identyczne. Cele kształcenia na wyższym poziomie merytorycznie różnią się od celów kształcenia na poziomie niższym komponentem z zakresu historii etyki oraz postulatem angażowania się ucznia na rzecz wspólnego dobra. Nie reprezentują, w naszej ocenie, spójnej wizji aksjologicznej współczesnego świata, z której wyprowadzono by konkluzje pedagogiczne. Pozostają $\mathrm{w}$ niedookreślonej relacji $\mathrm{z}$ treściami nauczania. Promują rozumienie wychowania moralnego jako intelektualnej recepcji określonych elementów „wiedzy etycznej”. W żadnym spośród wymagań ogólnych nie dostrzegamy postulatu rozwijania u uczniów umiejętności namysłu nad zjawiskami moralnymi oraz zaangażowania $\mathrm{w}$ podmiotowe współtworzenie wspólnoty moralnej. Formuła zawarta w 9 punkcie oraz jej rozwinięcie w treściach nauczania (zwłaszcza fragmencie IV) świadczy, że wielokrotnie obecny $\mathrm{w}$ dokumencie motyw uczestniczenia we wspólnocie zawarowuje model partycypacji biernej, adaptacyjnej, nie zaś aktywnej, inicjującej i współkonstytuującej wspólnoty. Takie ujęcie jest nie tylko anachronizmem, przywołującym modele społeczeństwa przedobywatelskiego, ale jako takie zaprzecza elementarnym doświadczeniom współczesnych dzieci i młodzieży (funkcjonujących w rozmaitych wspólnotach formalnych i nieformalnych).

Niestaranność językowa Autorów, widoczna we fragmencie dotyczącym edukacji wczesnoszkolnej i przeniesiona do omawianej części poprzez przekopiowanie szeregu sformułowan, przechodzi w niechlujność: w ramach przedrozumienia wybranych pojęć moralnych, uczeń zna i objaśnia wybrane 
pojęcia moralne (na niższym poziomie edukacyjnym uczniowie znali i objaśniali część tych pojęć bez ram przedrozumienia). Strategia kategorialnego doboru pojęć moralnych również wydaje się chybiona, skoro w jednym rzędzie obok dobra i zła moralnego, wartości moralnej, obowiązku moralnego itp. pojawia się bohaterstwo.

Z projektu podstawy programowej wyłania się następujący obraz wspierania ucznia w rozwoju. W świetle części II wymagań szczegółowych: w okresie edukacji wczesnoszkolnej wysiłek nauczyciela ma zmierzać do tego, aby uczeń starał się okazywać szacunek różnym osobom, natomiast na poziomie wyższym nauczyciel ma zmierzać do tego, aby uczeń wiedział, że należy okazywać szacunek innym osobom. Podobny progres metodyczny nauczyciela i moralny ucznia zaplanowano w III punkcie. Najwyraźniej wizjonerski zapał opuścił Autorów przy punkcie IV, w którym uczniowie pozostają na tym samym poziomie kompetencyjnym, który wyznaczał cele etycznej edukacji wczesnoszkolnej. $\mathrm{Na}$ szczęście, w odróżnieniu od ucznia klas I-III, który wie, dlaczego nie powinno się krzywdzić zwierząt, uczeń klas IV-VIII zarazem wie, jak i nie krzywdzi.

Istotne novum wobec wcześniejszego poziomu edukacyjnego wnosi punkt VI Wybrane stanowiska i problemy $w$ etyce. W odniesieniu do wskazanego historycznoetycznego komponentu projektu podstawy programowej etyki do szkoły podstawowej mamy następujące uwagi.

Z perspektywy potrzeb ucznia, specyfiki procesów rozwojowych i specyfiki wyzwań moralnych współczesności dokonany wybór ,etyk wybranych filozofów" jest absolutnie niezrozumiały, wywołuje wrażenie hermetycznego $\mathrm{i}$ arbitralnego. Uznanie doniosłego znaczenia w historii kultury europejskiej Sokratesa, Arystotelesa, epikureizmu, stoicyzmu, tomizmu, Tadeusza Kotarbińskiego i Karola Wojtyły nie prowadzi do prostej konkluzji, że zapoznanie się $\mathrm{z}$ uproszczoną wizją wywodzących się z tych tradycji moralnych wskazówek jest w stanie ubogacić moralnie uczniów. Wyłączność argumentu z doniosłości historycznej może budzić wątpliwości nawet w przypadku selekcji treści nauczania na historii. Ponadto przygotowany wybór stanowisk i problemów etycznych nie uwzględnia różnic rozwojowych wpisanych w rozpiętość wiekową uczniów klas IV-VIII. Jakkolwiek Autorzy zdają się mieć świadomość, że etyka ma charakter praktyczno-wychowawczy (trzeci akapit w Warunkach realizacji), to jedynie w odniesieniu do etyki Karola Wojtyły rozpoznają możliwość praktycznego zastosowania przez uczniów zdobytej wiedzy. Na dodatkową uwagę zasługuje zdanie z części Warunki realizacji, dotyczące historycznoetycznego komponentu: Zaleca się, aby nauczyciele etyki przygotowujac tę tematykę zajęć z etyki wprowadzali te treści jako elementy dopetniajace (korespondujace) edukacje polonistyczna, historyczna, inna. Trudno nie ulec wrażeniu, że Autorzy po prostu odrzucają egzystencjalną doniosłość edukacji etycznej jako wartości autotelicznej. Ostatecznie - w ich ujęciu - swoją rację bytu etyka jako przedmiot szkolny uzyskuje poprzez to, że 
wesprze inne przedmioty szkolne. $Z$ naszej perspektywy o wiele fortunniej byłoby, gdyby to edukacja polonistyczna, historyczna... dopełniała etyczny rozwój ucznia.

Upierając się przy tym, że sensem edukacji etycznej jest wspieranie ucznia $\mathrm{w}$ jego rozumieniu siebie, także $\mathrm{w}$ relacjach $\mathrm{z}$ innymi osobami oraz bytami, podkreślamy, że nasze doświadczenie metodyczne uczy, że w przypadku etyki optymalna jest organizacja treści nauczania w porządku problemowym, konstruowanym $\mathrm{w}$ oparciu o rozpoznanie sytuacji aktualnej i dobieranie takich kontekstów historycznych, które wnoszą coś ważnego do rozumienia owej sytuacji. W planowaniu nauczania etyki gruntowny namysł nad aktualnymi warunkami dokonywania wyborów moralnych powinien prowadzić do wyselekcjonowania tych elementów tradycji etycznej, które są w stanie uczynić te warunki bardziej przejrzystymi.

W doświadczeniu młodego człowieka ważne są trudności i konstruktywne radzenie sobie z nimi. Dziecko i nastolatek, poprzez podejmowanie takich czy innych działań, wypracowuje indywidualne strategie rodzenia sobie $\mathrm{z}$ trudnościami, które w znacznym stopniu wyznaczą jego szanse i ograniczenia życiowe. Dlatego tak ważne dla aktualnego i przyszłego życia, w tym moralnego, ucznia jest umożliwienie mu rozpoznania pozytywnej roli trudności w procesie rozwoju, uświadomienie obecności oraz znaczenia dyskomfortu i niepowodzenia w życiu ludzkim, wyposażenie w „narzędzia” radzenia sobie z trudnościami, dawkowanie odpowiedniej dozy trudności $w$ organizowanych doświadczeniach edukacyjnych. Są to szczególnie ważne wyzwania edukacyjne w kulturze konsumpcyjnej i w kontekście współczesnych postaw wychowawczych, które nierzadko cechuje nadopiekuńczość rodzicielska, co doprowadza do dużych deficytów samodzielności i odpowiedzialności dzieci i młodzieży. Treści te są równie istotne $\mathrm{w}$ wypadku prób edukacyjnego przeciwdziałania reprodukcji biedy i społecznej bezradności. Kiedy właściwie zdefiniujemy wymóg edukacyjny, należy dobrać do niego kontekst teoretyczny, który pozwoli go przepracować w sposób pogłębiony. Zapewne spośród wskazanych przez Autorów dyskursów etycznych dałoby się wybrać elementy, które wzbogaciłyby horyzont namysłu nad znaczeniem wysiłku i trudu w życiu ludzkim, ale dla analizy problemowej najważniejsze jest zorganizowanie sytuacji wielokontekstowego rozpoznania zjawiska przez uczniów, nie zaś podporządkowanie się chronologicznym cezurom.

Porządnie opracowane podstawy programowe $\mathrm{z}$ etyki powinny wychodzić od zdiagnozowanych potrzeb edukacyjnych uczniów i oferować wyselekcjonowane źródła i konteksty historyczne. Aktualny projekt opiera nauczanie etyki o indywidualne preferencje intelektualne Autorów, skazując nauczyciela albo na konformistyczne podporządkowanie się wyartykułowanym wymogom, kosztem pedagogicznego sensu takich działań, albo na odpowiedzialność samodzielnych 
poszukiwań fundamentalnych pytań i problemów, dodając mu zadanie „doklejenia" treści z podstaw do tego, czym wedle nauczycielskiej etyki zawodowej powinien się zajmować w pracy.

Fragment Warunki realizacji w znacznej części wiernie skopiowany z wcześniejszego poziomu edukacyjnego posiada wszystkie wskazane już przez nas słabości swojego pierwowzoru.

Podobnie jak w przypadku I poziomu edukacyjnego, przeprowadzona przez nas analiza nie jest wyczerpująca, z powodu krótkiego terminu prekonsultacji ograniczyliśmy się do omówienia najważniejszych dla nas kwestii.

Wrocław, dnia 9 grudnia 2016 roku

\section{NOTY O AUTORACH}

Wiktor Figiel - nauczyciel przedmiotów filozoficznych w gimnazjum oraz liceum. Współpracuje przy filozoficznych inicjatywach edukacyjnych dla młodzieży (Anima(cje) Filozofii przy Instytucie Filozofii Uniwersytetu Wrocławskiego: Jestem z Wrocławia, więc myślę, Porzadne myślenie). Trener programu Destination Imagination, opiekun gimnazjalnych i licealnych drużyn debatanckich.

Andrzej Krajna - polonista, redaktor naczelny Pracowni Ewaluacji Wewnętrznej i Wydawnictw Centrum Edukacji Nauczycielskiej Uniwersytetu Wrocławskiego, zajmuje się teorią i praktyką konstruktywizmu, prowadzi badania nad rozumieniem pojęc i przekazywaniem wiedzy z tych obszarów przyszłym i obecnym nauczycielom, współautor książek naukowo-metodycznych, propagujących stosowanie zasad konstruktywizmu w praktyce nauczycielskiej. Nagrodzony Medalem Komisji Edukacji Narodowej.

Katarzyna Kuczyńska - konsultant we Wrocławskim Centrum Doskonalenia Nauczycieli, nauczycielka etyki i filozofii pracująca na wszystkich poziomach edukacyjnych. Pomysłodawczyni i inicjatorka różnorodnych przedsięwzięć z zakresu edukacji filozoficznej (np. Anima(cje) Filozofii, Jestem z Wrocławia, więc myśle, Porzadne myślenie, Kącik Sokratesa). Autorka pracy doktorskiej z filozofii edukacji, swoje działania teoretyczne określa mianem budowania filozofii sytuacji dydaktycznej.

Elżbieta Małkiewicz - doktor psychologii, psycholog rozwojowy, terapeuta dziecięcy, nauczyciel akademicki na Uniwersytecie Wrocławskim, uczący przyszłych i obecnych nauczycieli zarówno teorii, jak i praktyki (zajęcia dydaktyczne, warsztaty, praktyki studenckie, projekty edukacyjne). Współautorka książek naukowo-metodycznych, propagujących stosowanie zasad konstruktywizmu w praktyce nauczycielskiej. Nagrodzona Medalem Komisji Edukacji Narodowej.

Wojciech Ostrowski - doktor filozofii, kierownik Pracowni Dydaktyki Filozofii IF Uniwersytetu Wrocławskiego, współtwórca projektu Anima(cje) Filozofii oraz innych przedsięwzięć edukacyjnych, autor prac i programów dotyczących nauczania filozofii.

Krystian Piątek - nauczyciel etyki w Szkole Podstawowej nr 63 oraz w Zespole Szkolno-Przedszkolnym nr 16 we Wrocławiu. Uczestnik projektu Jestem z Wrocławia więc myślę. Student pedagogicznych studiów magisterskich na Uniwersytecie Wrocławskim. Absolwent studiów filozoficznych pierwszego stopnia na Uniwersytecie Wrocławskim. 
Aldona Pobojewska - profesor doktor habilitowana filozofii, zatrudniona w Katedrze Etyki Uniwersytetu Łódzkiego. Autorka licznych tekstów z zakresu epistemologii i filozofii edukacji, publikowanych w naukowych czasopismach polskich i niemieckich. Nagrodzona Medalem Komisji Edukacji Narodowej. Rzeczoznawczyni MEN ds. szkolnych podręczników filozofii i etyki. Prezes Stowarzyszenia Edukacji Filozoficznej „Phronesis”. Prowadzi zajęcia z dydaktyki filozofii dla studentów i nauczycieli.

Maria Reut - doktor habilitowana, filozof, pedagog, prof. Dolnośląskiej Szkoły Wyższej we Wrocławiu. Jej zainteresowania filozoficzne koncentrują się wokół hermeneutyki, filozofii kultury i filozofii sztuki (w szczególności koncepcje narracji i tożsamości narracyjnej). Zajmuje się również problematyką edukacji z wielu perspektyw: filozofii edukacji, pedagogiki krytyczniej i hermeneutycznej, etyki, antropologii współczesności. Interesują ją również koncepcje kształcenia nauczycieli.

Sebastian Wachowiak - filozof i pedagog; nauczyciel etyki oraz filozofii w publicznej szkole podstawowej oraz niepublicznej wrocławskiej Małej Uczelni; zaangażowany w promowanie i rozwijanie edukacji filozoficznej we Wrocławiu. Dbałość o przedmiotową kulturę dydaktyczną pielęgnuje poprzez udział w rozmaitych projektach na obrzeżach edukacji publicznej (Anima(cje) Filozofii, Jestem z Wrocławia, więc myślę, Porządne myślenie).

Pawel Wróblewski - doktor filozofii, zastępca dyrektora Instytutu Filozofii Uniwersytetu Wrocławskiego ds. dydaktycznych, członek The International Council of Philosophical Inquiry with Children; uczestnik wielu inicjatyw popularyzujących edukację filozoficzną w obszarze pozauczelnianym (m.in. Wroctawska Wszechnica Filozoficzna, Filozoficzne Wtorki w Panato Cafe); zajmuje się historią filozofii antycznej i średniowiecznej oraz recepcją tej myśli w epokach późniejszych, filozofią religii oraz studiami nad dialogiem międzykulturowym i międzyreligijnym.

Jolanta Zwiernik - doktor habilitowana, prof. Dolnośląskiej Szkoły Wyższej we Wrocławiu. Specjalistka w zakresie pedagogiki przedszkolnej i wczesnoszkolnej, socjografii dzieciństwa (warunki życia dziecka), pedagogiki społecznej, socjologii edukacji oraz teorii wychowania. Od 2008 roku kieruje Zakładem Edukacji Wczesnoszkolnej Instytutu Pedagogiki DSW oraz należy do Zespołu Edukacji Elementarnej Komitetu Nauk Pedagogicznych PAN.

\section{A COMMENTARY ON THE PUBLISHED PROJECT OF CORE CURRICULA IN ETHICS IN PRIMARY SCHOOL}

The text is a commentary on the project of core curricula in ethics, which was published by the Polish Ministry of Education in 2016 in connection with the reform of education in Poland. The authors draw attention to the shortcomings of the project: narrowing of the subject of ethics to learned norms of behaviour, excessive emphasis on conceptual knowledge instead of training students' reflecting skills by means of discussion and problem solving. They also point to the programs' maladjustment to the level of psycho-emotional development of students at this stage, and lack of consistency between particular assumptions of the project.

\section{Keywords:}

ethics at school, core curriculum, primary education in Poland 